\title{
Temporal Trends over a Decade of Defibrillator Therapy for Primary Prevention in Community Practice
}

Serge Boveda, ${ }^{1}$ MD, Kumar Narayanan, ${ }^{2} \mathrm{MD}$, Sophie Jacob,${ }^{3} \mathrm{PhD}$, Rui Providencia, ${ }^{1} \mathrm{MD}, \mathrm{PhD}$, Frankie Beganton, ${ }^{2} \mathrm{MPH}$, Vincent Algalarrondo, ${ }^{4} \mathrm{MD}, \mathrm{PhD}$, Pascal Defaye, ${ }^{5} \mathrm{MD}$, Marie-Cécile Perier, ${ }^{2}$ MPH, Nicolas Sadoul, ${ }^{6}$ MD, PhD, Olivier Piot, ${ }^{7}$ MD, Didier Klug, ${ }^{8}$ MD, PhD, Daniel Gras, ${ }^{9}$ MD, Laurent Fauchier, ${ }^{10} \mathrm{MD}$, PhD, Pierre Bordachar, ${ }^{11} \mathrm{MD}, \mathrm{PhD}$, Dominique Babuty, ${ }^{10} \mathrm{MD}, \mathrm{PhD}$, Jean-Claude Deharo, ${ }^{12} \mathrm{MD}, \mathrm{PhD}$, Christophe Leclercq, ${ }^{13} \mathrm{MD}$, PhD, Eloi Marijon, ${ }^{2,10,11} \mathrm{MD}, \mathrm{PhD}$; on Behalf of the DAI-PP Investigators

From:

${ }^{1}$ Clinique Pasteur, Toulouse, France

${ }^{2}$ Paris Cardiovascular Research Center (Inserm U970), Paris, France

${ }^{3}$ IRSN, Laboratory of Epidemiology, Fontenay-aux-Roses, France

${ }^{4} \mathrm{CHU}$ Antoine Béclère, Clamart, France

${ }^{5} \mathrm{CHU}$ Michallon, Grenoble, France

${ }^{6} \mathrm{CHU}$ Brabois, Nancy, France

${ }^{7}$ Centre Cardiologique du Nord, Saint Denis, France

${ }^{8} \mathrm{CHRU}$ Lille, Lille, France

${ }^{9}$ Nouvelles Cliniques Nantaises, Nantes, France

${ }^{10} \mathrm{CHU}$ Trousseau, Tours, France

${ }^{11} \mathrm{CHU}$ Haut Lévêque, Bordeaux, France

${ }^{12} \mathrm{CHU}$ La Timone, Marseille, France

${ }^{13} \mathrm{CHU}$ Pontchaillou, Rennes, France

${ }^{10}$ European Georges Pompidou Hospital, Paris, France

${ }^{11}$ Paris Descartes University, Paris, France

\section{Corresponding author}

Eloi Marijon, $\mathrm{MD}, \mathrm{PhD}$

Département de Cardiologie

Hôpital Européen Georges Pompidou

20-40 Rue Leblanc, 75908 Paris, France

Tel : +33156093692

Fax : +33156092664

E-mail : eloi.marijon@inserm.fr

Original Paper - Journal of Cardiovascular Electrophysiology

Word Count: 3,156 


\section{Abstract (Word count: 250)}

Background - Technology and clinical practice surrounding the use of the primary prevention implantable cardioverter defibrillator (ICD) are in a state of constant evolution. The purpose of the study was to test the hypothesis of significant temporal trends in characteristics and outcomes over a decade of ICD therapy.

Methods - Between 2002-2012, 5,539 consecutive patients (age 62.5 \pm 11 years, $84.9 \%$ male), with ischemic or non-ischemic cardiomyopathy, implanted with a primary prevention ICD from 12 centres in France were included. Information on characteristics and outcomes (including causes of death) were evaluated over a median follow-up of 994 days [466-1,667]. Results - In addition to a shift in the type of devices implanted with a significant increase in cardiac resynchronization therapy-defibrillator (CRT-D) over time (43.6 to 60.4\%, $P=0.0001$ ), an increase in mean age (from $61.5 \pm 11.6$ to $63.2 \pm 10.9$ years, $P=0.0016$ ), proportion of non-ischaemic cardiomyopathy (31.0 to $44.7 \%, P<0.0001)$ and women recipients (11.4 to $15.8 \%, P=0.004)$ was observed. A total of 1,181 patients $(22.3 \%)$ received $\geq 1$ appropriate therapy, inappropriate therapies occurred in 355 patients $(6.7 \%)$ and 826 patients (15.2\%) died, mainly from cardiovascular causes (49.3\%). Annual mortality incidence $(5.4 \%$ to $4.3 \%, P=0.05)$, as well as incidence of appropriate therapy ( $10.4 \%$ to $7.1 \%, P=0.0004)$, significantly decreased over the decade. By contrast, incidence of ICDrelated late (>30 days after implant) complications significantly increased (4.6 to $7.6 \%$, $P=0.003)$.

Conclusion - Our findings demonstrate significant changes in patterns of use and outcomes in primary prevention ICD over the last decade with reductions in mortality and appropriate therapies, counterbalanced by an increase in complications.

Key Words: Sudden cardiac death; sudden death prevention; implantable cardioverter defibrillator 


\section{Introduction}

Over the last decade, use of implantable cardioverter defibrillators (ICDs) for primary prevention of sudden cardiac death (SCD) has become an important part of the management of high-risk patients with severe left ventricular (LV) systolic dysfunction as evidenced by a depressed ejection fraction (EF). ${ }^{1}$ This therapy is now recommended as a Class I indication with the highest level of evidence in the practice guidelines issued by the European and American Heart Associations., 2, 3, 4

Technology and clinical practice surrounding the primary prevention ICD has continually evolved and real-world data evaluating temporal trends in outcomes with ICD therapy, especially in Europe are scarce. This is particularly important both in terms of understanding the impact of the ICD in current clinical practice, as well as to identify potential areas for improvement. Data available on temporal trends in North America have relied on large administrative databases and claims data, which, while valuable, have some inherent limitations as opposed to direct access to patient medical records and physicianguided adjudication of outcomes. ${ }^{5}$ In addition, to the best of our knowledge, temporal trends for appropriate therapies, and specific causes of death of primary prevention ICD patients have not been addressed so far. ${ }^{6-8}$

For these purposes, the DAI-PP registry was specially developed in order to provide a large national database precisely describing the epidemiological data and outcomes (including causes of death) in a well-defined population of patients treated with a primary prevention ICDs, within a well-established network for the treatment of cardiac arrhythmias in France. 


\section{Methods}

The DAI-PP study (Défibrillateur Automatique Implantable-Prévention Primaire,) was a retrospective analysis of all subjects with ischaemic or non-ischaemic cardiomyopathy implanted with a primary prevention ICD, between 2002 and 2012 in 12 French centres. ${ }^{9-11}$ The data were collected according to a standardised and homogeneous process, using a similar electronic form. The study was funded by public sources, including the French Institute of Health and Medical Research (INSERM) and the French Society of Cardiology, and was coordinated by Clinique Pasteur, Toulouse and the Paris Cardiovascular Research Center, European Georges Pompidou Hospital, Paris. The study was also approved by the Institutional Review Board of each participating hospital, registered on ClinicalTrials.gov (NCT01992458), and the data file of the DAI-PP study was declared to and authorized by the French data protection committee (Commission Nationale Informatique et Liberté, CNIL, $\left.\mathrm{N}^{\circ} 913203\right)$.

The Cardiovascular Epidemiology Unit from the Paris Cardiovascular Research Center (INSERM Unit 970) was in charge of quality control and storage of all data as well as the statistical analyses, which had been planned and approved by the Steering Committee (appendix).

\section{Study population}

Consecutive patients with ischaemic or non-ischaemic dilated cardiomyopathy implanted with single, double or triple chamber ICD for primary prevention between 2002 and 2012 were enrolled.

To qualify for the study, patients had to be at least 18 years-old at the time of ICD implantation. Overall, all patients with ischaemic or non-ischaemic cardiomyopathy, implanted with an ICD (single, double or triple chamber) in the setting of primary prevention were considered and enrolled in the DAI-PP follow-up program. Ischaemic cardiomyopathy was 
defined as presence of depressed LVEF due to a previous myocardial infarction, or developed in the setting of significant coronary artery disease with or without history of angioplasty or bypass graft surgery performed $\geq 3$ months before device implantation. All other patients were classified as suffering from non-ischaemic cardiomyopathy. Primary prevention was defined as no prior documented history of sudden cardiac arrest and/or ventricular tachycardia/fibrillation. Exclusion criteria encompassed patients $<18$ years of age, those with an ICD implant for secondary prevention or for primary prevention without structural heart disease (including Brugada, long QT syndrome among others) or structural heart disease other than ischaemic or non-ischaemic cardiomyopathy (hypertrophic cardiomyopathy, noncompaction cardiomyopathy and arrhythmogenic right ventricular dysplasia).

Patients were characterised at the time of ICD implantation. All variables at the time of the procedure were defined and categorized according to the literature or common practice. In addition to the New York Heart Association (NYHA) functional class, we noted the aetiology of the underlying heart disease (ischaemic or non-ischaemic cardiomyopathy). Glomerular filtration rate (GFR), was estimated with the Cockroft-Gault formula and categorized in two categories ( $\geq 60$ and $<60 \mathrm{~mL} / \mathrm{min}$ ); QRS duration was categorized as $<120$ and $\geq 120 \mathrm{~ms}$. Atrial fibrillation (AF) was defined as a history of AF (paroxysmal or persistent), documented on ECG or 24-hour Holter monitoring. Co-morbidities were systematically collected: cancer, chronic obstructive pulmonary disease, chronic renal failure, chronic liver disease, history of transient ischaemic neurological attack, and others (including diabetes mellitus). The type of implanted ICD device (biventricular, single chamber or dual chamber - without manufacturer information) was recorded, and device programming was left at the treating physician's discretion. Except specific clinical situations, the use of 2 zones with high rate (VT>180 bpm; VF above $220 \mathrm{bpm}$ ) programming were encouraged according to the Cardiac Arrhythmias Group of the French Society of Cardiology internal 
consensus at this time. Information on medication at hospital discharge was collected, including beta-blockers, amiodarone, Ic class anti-arrhythmics, sotalol, digoxin, calcium blockers, angiotensin-converting enzyme inhibitor or angiotensin II receptor blocker, diuretics, anti-platelets, and vitamin $\mathrm{K}$ antagonists.

\section{Patient follow-up, clinical outcomes and study endpoints}

Follow-up information was obtained from regular appointments every 4 to 6 month for device evaluation. ${ }^{12,13}$ The different endpoints were: occurrence of appropriate therapies, inappropriate therapies and other complications, as well as overall and specific mortalities. Device interrogation printouts were checked by the lead-investigator at each site for appropriate and inappropriate ICD therapy. Based on this follow-up information, the longterm clinical endpoints of this study included i) mortality and specific causes of death, ii) delivery of appropriate therapies, and iii) ICD-related late (defined as occurring $>30$ days after implant) adverse effects including inappropriate shock(s).

The vital status was ascertained by review of the patients' medical files from the hospital or by communication with primary physicians and finally corroborated with the French vital status database of the National Institute of Economic Statistics. In case of death, the specific cause(s) was collected from the patients' files, complemented by information from the national database available at the French Centre on Medical Causes of Death (Centre d'Epidémiologie sur les Causes Médicales de Décès - CépiDc, Inserm). Each death was reviewed by two investigators and, whenever possible, classified as sudden arrhythmic or non-arrhythmic, end stage heart failure, ICD-related, or from another cardiovascular, or non-cardiovascular cause.

Appropriate ICD therapy was defined as the successful termination of an episode of sustained VT or VF by single or multiple shocks, antitachycardia pacing, or both. The date of first appropriate ICD therapy and the number of appropriate therapies delivered during follow-up were recorded. 
ICD-related, non-fatal, late adverse events included infections, lead dislodgement or dysfunction and inappropriate therapies.

\section{Statistical analysis}

Data from the DAI-PP registry were used for analyses of clinical characteristics, and outcomes for all implanted patients. In addition, in order to identify temporal trends during the period 2002 -2012, we arbitrarily decided to cut it in three periods (2002-2005; 2006$2009 ; 2010-2012)$ in order to provide comparison results between ancient and more recent periods of implantation and all these data were carefully analysed through these 3 time periods of implantation. The results are presented as means \pm standard deviation, medians [interquartile ranges] or counts and percentages. Time to event for different outcomes being available, annual incidence rates could be calculated based on the exact number of personyears of follow-up. The chi-square test was used to compare categorical variables and Student's $t$-test to compare continuous variables. Levene's test was used to verify the homogeneity of variance. Equivalent, non-parametric tests were used when the KolmogorovSmirnov test indicated an absence of normal distribution. A Cox regression analysis was used to identify risk factors for different outcomes, with competing risk analysis option for ICD therapy endpoints (competing with death), with corresponding hazard-ratios (HR) and 95\% confidence intervals (CI). Preliminary proportional hazards assumption was validated for the Cox model after checking in univariate analysis that time dependent covariates included in the Cox model by creating interactions of the predictors and a function of survival time were not significant. All covariates that reached $\mathrm{P}<0.02$ significance level in univariate analysis were then included in an initial multivariable regression model. A backward stepwise selection was applied to obtain final model that included covariates with $\mathrm{P}<0.05$. In all risk analysis, potential impact of clustering of patients within hospitals was tested by adding hospital (into four categories, according to public/private as well as volume of activity per 
year) as a variable in models. The reported p-values are two-sided. P-values $<0.05$ were considered statistically significant. All data were analysed using the SAS program v9.4 (SAS Institute Inc., Cary, NC).

\section{Results}

\section{Patients' characteristics}

A total of 5,539 patients implanted between 2002 and 2012 were included in the DAI-PP program (Table 1). Mean age was 62.5 years (SD 11.2 years), $84.9 \%$ were men and $60.2 \%$ presented with ischaemic heart disease. A history of AF was confirmed in $24.0 \%$ of the sample, $48.8 \%$ were in New York Heart Association (NYHA) functional class III or IV, moderate to severe renal dysfunction was present in nearly $40 \%$ of patients, including 280 $(8.7 \%)$ of patients who had a GFR less than $30 \mathrm{~mL} / \mathrm{Min}$. Beta-adrenergic blockers and angiotensin-converting enzyme inhibitors or angiotensin II receptor blockers were both prescribed in over $80 \%$ of patients. Single-chamber ICDs were implanted in 1,258 (22.9\%), dual-chamber in 1,280 (23.3\%) and CRT-Ds in 2,952 (53.8\%) patients.

The patients' baseline characteristics and temporal trends over the 3 time periods are presented in Table 1. The mean age of implanted patients significantly increased from 2002 to $2012(61.5 \pm 11.6$ vs. $63.2 \pm 10.9$ years, $P=0.0016)$. The relative proportion of women $(11.4$ vs. $15.8 \%, P=0.0038)$ as well as that of non-ischaemic cardiomyopathy (31.0 vs. $44.7 \%$, $P<0.0001)$ increased. A significant increase was observed in the proportion of CRT-Ds implanted over the 10 years of the registry ( 44.1 vs. $60.1 \%, P<0.0001)$, representing $>50 \%$ of all devices implanted after year 2008 (Figure 1). The proportion of patients prescribed with appropriate guideline-directed heart failure therapy, including beta-adrenergic blockers (78.8 vs. $87.2 \%, P<0.0005)$ and angiotensin converting enzyme inhibitors /angiotensin II receptor blockers (76.4 vs. $88.0 \%, P=0.01)$ increased over time. Diuretics (57.6 vs. $71.3 \%, P=0.002)$ 
and antiplatelet use (50.9 vs. $60.7 \%, P=0.01)$, also increased, while rates of vitamin $\mathrm{K}$ antagonists $(P=0.32)$, amiodarone $(P=0.81)$, digoxin $(P=0.86)$, and spironolactone $(P=0.98)$ remained relatively stable. Performance of defibrillation testing during implantation significantly decreased over the decade (from 78.0 to $64.1 \%, P<0.0001$ ).

\section{Overall and specific mortalities, appropriate therapies, and complications}

Among the 5,539 patients, median follow-up was 994 days, IQR [466 - 1,667], based on median value of observation times distribution (difference between the date of death or last follow-up and the date of implantation), corresponding to 16,788 person-years of follow-up data.

Overall, 826 patients died (15.2\%), corresponding to an annual incidence of $4.9 \%$ (95\% CI 4.5-5.2). The multivariate Cox analysis of overall mortality showed a significant association with history of AF (HR 1.41, 95\% CI 1.13-1.77, $P=0.003$ ), NYHA functional class $\geq$ III (HR 2.25, 95\% CI 1.81-2.79, $P<0.001)$, LVEF $<30 \%$ (HR 1.50, 95\% CI 1.21-1.86, $P<0.001)$ at the time of device implantation, ischaemic cardiomyopathy (HR $1.66,95 \% \mathrm{CI}$ 1.34-2.00, $P<0.001$ ), and a GFR $\leq 60 \mathrm{ml} / \mathrm{min}$ (HR 2.31, 95\% CI 1.88-2.84, $P<0.001$ ) (Table 2). A specific cause of death was ultimately identified in 682 out of 826 deceased patients $(82.6 \%)$. End-stage heart failure was the main cause of death accounting for 357 deaths (52.3\%), corresponding to an annual incidence of $2.4 \%$ (95\% CI 2.2-2.7). Annual mortality rate decreased over time, from $5.4 \%$ (95\% CI 4.5-6.3) in 2002-2005, to $4.4 \%$ (95\% CI 3.8 5.0) in $2006-2009$, and $4.3 \%(95 \%$ CI 3.4-5.3) in 2009-2012 ( $P=0.05)$. This decrease in total mortality was mainly the result of a decrease in cardiovascular mortality (especially endstage heart failure), from an annual incidence rate of $2.9 \%$ (95\% CI 2.4-3.4) in 2002-2005, $2.3 \%$ (95\% CI 2.0-2.6) in 2006-2009, to $1.9 \%$ (95\% CI $1.3-2.5)$ in $2009-2012(P=0.01)$. 
Sudden cardiac death unresponsive to ICD, ICD-related fatal complications, as well as noncardiovascular mortality remained unchanged over time.

At least one appropriate therapy was delivered in 1,181 patients (22.3\%), with a median time to first appropriate therapy of 804 days [327-1,420], giving an average annual incidence of appropriate therapy over the entire time period (2002-2012) of 7.7\% (95\% CI 7.2-8.2). Over time, a highly significant decrease in the annual rate of appropriate therapies was observed from $10.4 \%$ (95\% CI 7.2-8.2) in 2002-2005, to $8.7 \%$ (95\% CI 7.8-9.7) in 20062009, and 7.1\% (95\% CI 5.8-8.4) in 2009-2012 ( $P=0.0004)$ (Figure 2).

A total of $824(15.5 \%)$ patients presented with at least one late complication. Overall, inappropriate therapies were observed in 355 patients, giving an annual incidence of 2.1 (95\%CI 1.8-2.6) per 100-patient-years. Over the three time periods, the overall late complication annual rate increased significantly $(P=0.003)$, from $4.6(95 \%$ CI $3.9-5.2)$ in 2002-2006, to $7.6 \%$ (95\% CI 6.4-8.9) in 2009-2012. This was mainly a result of an increase in lead dysfunction ( 2.3 to $5.2, P=0.0001$ ), whereas the incidence of inappropriate therapies remained stable ( 1.9 to $2.2 \%, P=0.23$ ). No significant differences in inappropriate therapies $(\mathrm{P}=0.23)$ as well as appropriate therapies rates $(\mathrm{P}=0.12)$ between centres were observed. When analysed separately, the subset of CRT-D patients had higher cardiovascular mortality during follow-up (HR 1.7, 95\%CI 1.4-2.2, P<0.0001), were less likely to have inappropriate therapy (HR 0.7, 95\% CI 0.5-0.8, $\mathrm{P}=0.02$ ), but had similar appropriate therapy rates (HR 0.9, 95\% CI 0.8-1.1, P=0.12), compared to patients implanted with only an single/dual ICD.

\section{Discussion}

Using a large, nationwide, multicentre registry with direct evaluation of patient data and physician-adjudication, we highlight important trends in ICD therapy and outcomes over the 
past decade. These results can be useful to guide future policy and identify areas for improvement.

We found significant changes in patient characteristics with older and relatively greater proportion of female and/or non-ischaemic cardiomyopathy patients being implanted. The latter is an interesting finding, considering the very recent published data from DANISH trial. ${ }^{14}$ Indeed, this trial suggests the lack of efficiency for mortality prevention in nonischemic cardiomyopathy patients implanted for primary prevention. ${ }^{14}$ The characteristics of the patients in our registry are broadly concordant with those patients included in previously published reports of "real world" national registries. ${ }^{15,16}$ Compared to one of the largest North American primary prevention registries, ${ }^{7}$ the mean age of our patients was somewhat lower (63 vs. 68 years), potentially suggesting a more conservative selection of candidates for primary prevention by French cardiologists in the early years of the registry. It is however noteworthy that the mean age, as well as comorbidity burden, of the ICD recipients increased over the ten-year duration of the registry, likely reflecting an improvement of physician's judgment of benefit and confidence related to the primary prevention ICD. ${ }^{17,18}$ The proportion of women implanted increased over time, though it still remains relatively low compared to men, in concordance with recent data from Italy showing a five-fold higher implantation rates among men. ${ }^{15}$ In similar fashion to randomized controlled trials and other registries of ICD recipients in daily clinical practice, women account for only a minority of our cohort, possibly caused by lower rates of referral of women to this therapy. ${ }^{19-23}$ Similarly, recent analysis of trends in the US suggest persisting sex disparities $;{ }^{24}$ clearly there is a need to better understand factors underlying these differences so that appropriate measures can be instituted to optimize ICD use in all subgroups. With regard to device types, the proportion of CRT-D increased significantly, reaching over $60 \%$ in the last three years of the study; a change consistent with the on-going expansion of CRT indications, ${ }^{25}$ and also a significant 
switch from CRT-P to CRT-D in elderly patients. Encouragingly, rates of appropriate heart failure medical therapy have increased over time, as in the US. ${ }^{24-26}$

The overall death rate observed over a median follow-up of 3 years in our study (4.9\%) is concordant with the findings of ICD-treatment arms of the large randomized trials MADIT II and SCDHefT, ${ }^{27,28}$ and with recently updated data from a US registry. ${ }^{7}$ Adjusted annual overall mortality declined over the past decade, in line with the trend of declining death rates in the heart failure population in Europe and other parts of the world. To the best of our knowledge, we have provided the first data on temporal changes in specific mortalities in an unselected population of primary prevention ICD recipients. ICD-unresponsive sudden mortality remains low and relatively more progressive heart failure deaths were noted, highlighting the issue of competing risks for mortality.

The average annual incidence of appropriate therapies decreased significantly over the time course of this study. While this may partly relate to extension of primary prevention to potentially lower risk-profile candidates (at probably lower risk of VT/VF), this is also likely to be related to improvements in medical management of heart failure over time and improvement in programming towards less aggressive therapies and longer detection times, which may help reduce mortality as well. ${ }^{16}$

Device complications, including infection and lead-related problems, increased over the period of this study. Infections in particular, have been a source of concern with some studies from the US showing rise in infection rates disproportionate to the increase in number of devices implanted. ${ }^{29}$ Increase of lead-related problems seems also logical as the rate of CRT-D devices increased dramatically over time in the registry. Inappropriate therapies, did not significantly change over time. This information is reassuring, as inappropriate shocks are not only unpleasant but known to be associated with higher mortality and healthcare costs. ${ }^{16,30}$ Two large randomized trials have reported reduced rates of delivery of 
inappropriate therapies by thoughtful programming of devices. ${ }^{31,32}$ In recent years, several reports have emerged that have highlighted the strong association between ICD therapies and increased mortality. ${ }^{33}$ In prior analyses of both the MADIT II and SCD-HeFT trials, ICD therapies (mostly shocks) were associated with a greater than 3-fold increase in all-cause mortality. ${ }^{34,35}$ Considering both together shocks and ATP in our study (ATP for which the association with mortality is still unclear) may have participated to the lack of association after multiple adjustment. It is still not certain whether this association indicates a direct harmful effect of ICD therapy, or whether ICD therapies act as a marker for more severe underlying cardiac disease. Although appropriate shocks have consistently been shown to be associated with a significantly worse outcome, the same is less clear for inappropriate shocks. Analyses from both SCD-HeFT and MADIT II trials showed that inappropriate shocks were associated with an approximate 2 -fold increase in all-cause mortality. ${ }^{34,35}$ In contrast, 3 other studies found no association between inappropriate shocks and increased mortality. ${ }^{36-39}$

This registry is one of the first large-scale evaluations of primary ICD implantation in Europe; however it has some limitations. First, ICD programming was left to the discretion of individual physicians/centers and therefore could result in some variability. However, as previously explained, there exists a broad expert consensus among the senior investigators from each center in terms of ICD programming, namely use of generally high ventricular rates and fewer zones. Therefore we feel that major heterogeneity in programming type between centers is unlikely, as suggested by the absence of any significant differences centres. Second, while the median follow-up time (2.7 years) may appear relatively short, this is mainly related to a relatively greater number of patients were enrolled in the later stages of the study with shorter duration of follow-up till censure. This is in keeping with the dramatic increase in primary prevention ICD implantation rates in recent times. Third, because we did not collect data stratified by brands as well as details on single/dual coil implant, we were 
unable to test any differences in outcomes, although previously reported.$^{40}$ Finally, the accurate identification and sub-classification of specific causes of death is a very difficult and challenging task, which remained undetermined in nearly $20 \%$ of our study population, in line with previously published prospective cohort studies. ${ }^{41}$

\section{Conclusion}

Real world data from a population of primary prevention ICD recipients over the past decade in France demonstrate favourable trends, with increase in CRT devices, declining rates of overall mortality and appropriate therapy.

\section{Disclosures}

Dr. Boveda has received consulting fees from Medtronic, Boston Scientific, and Sorin Group. Dr. Sadoul has received personal fees from Biotronik, Boston Scientific, Medtronic, Sorin Group, and St. Jude Medical. Dr. Piot has received consulting honoraria from Medtronic and St. Jude Medical and research grants from Medtronic and Boston Scientific. Dr. Klug has received consultant fees from St. Jude Medical, Medtronic, Sorin Group, Boston Scientific, and Biotronik. Dr. Babuty has received travel support and clinical study support from Biotronik, Boston Scientific, Medtronic, St. Jude Medical, and Sorin Group. All other authors have reported that they have no relationships relevant to the contents of this paper to disclose.

\section{Acknowledgements}

We thank the investigators of the enrolling medical centres for participating in the study and sharing their data, the Research Associates Nicolas Estrugo, Sandrine Hervouet, Nathalie de Carsin, Radu Mosei, Juliette Tennenbaum, Raoul Hubac-Coupet, Alexandre Bendavid and 
Marine Sroussi for collecting the data, and the Arrhythmia Group of the French Society of Cardiology for supporting this project.

Funding: This work was supported by the following independent institutions: the Toulouse Association for the Study of Rhythm Disturbances, the French Institute of Health and Medical Research, and the French Society of Cardiology. 


\section{Appendix}

The following investigators and institutions participated in the conception of the registry, and in the organisation, collection, storage and analysis of the data:

Co-principal Investigators: Serge Boveda, MD, Clinique Pasteur, Toulouse; Eloi Marijon, MD, PhD, Hôpital Européen Georges Pompidou, Paris, France. Conceived, designed and organized the registry in 2009.

Co-investigators in charge of the data collection and analysis at each medical centre: Vincent Algalarrondo, MD, PhD, CHU Antoine Béclère, Clamart; Dominique Babuty, MD, PhD, CHU Trousseau, Tours; Pierre Bordachar, MD, PhD, CHU Haut Lévêque, Bordeaux; Serge Boveda, MD, Rui Providencia, MD, MS, Clinique Pasteur, Toulouse; Pascal Defaye, MD, CHU Michallon, Grenoble; Daniel Gras, MD, Nouvelles Cliniques Nantaises, Nantes; Jean-Claude Deharo, MD, PhD, CHU La Timone, Marseille; Didier Klug, MD, PhD, CHRU Lille, Lille; Christophe Leclercq, MD, PhD, CHU Pontchaillou, Rennes; Eloi Marijon, MD, PhD; Hôpital Européen Georges Pompidou, Paris; Olivier Piot, MD, Centre Cardiologique du Nord, Saint Denis; Nicolas Sadoul, MD, PhD, CHU Brabois, Nancy. Data storage, quality control, and statistical analyses: Frankie Beganton, MS, MarieCecile Perier, MS, Cardiovascular Epidemiology Unit, Paris Cardiovascular Research Center (INSERM Unit 970), Hôpital Européen Georges Pompidou, Paris.

Steering Committee: Serge Boveda, MD, Clinique Pasteur, Toulouse; Pascal Defaye, MD, CHU Michallon, Grenoble; Christophe Leclercq, MD, PhD, CHU Pontchaillou, Rennes; Eloi Marijon, MD, PhD; Hôpital Européen Georges Pompidou, Paris; Nicolas Sadoul, MD, $\mathrm{PhD}, \mathrm{CHU}$ Brabois, Nancy. 


\section{References}

1. Earley A, Persson R, Garlitski AC, Balk EM and Uhlig K. Effectiveness of implantable cardioverter defibrillators for primary prevention of sudden cardiac death in subgroups a systematic review. Ann Intern Med. 2014;160:111-21.

2. Zipes DP, Camm AJ, Borggrefe M, Buxton AE, Chaitman B, Fromer M, Gregoratos G, Klein G, Moss AJ, Myerburg RJ, Priori SG, Quinones MA, Roden DM, Silka MJ, Tracy C, Blanc JJ, Budaj A, Dean V, Deckers JW, Despres C, Dickstein K, Lekakis J, McGregor K, Metra M, Morais J, Osterspey A, Tamargo JL, Zamorano JL, Smith SC, Jr., Jacobs AK, Adams CD, Antman EM, Anderson JL, Hunt SA, Halperin JL, Nishimura R, Ornato JP, Page RL, Riegel B, American College of Cardiology/American Heart Association Task F, European Society of Cardiology Committee for Practice G, European Heart Rhythm A and the Heart Rhythm S. ACC/AHA/ESC 2006 guidelines for management of patients with ventricular arrhythmias and the prevention of sudden cardiac death--executive summary: A report of the American College of Cardiology/American Heart Association Task Force and the European Society of Cardiology Committee for Practice Guidelines (Writing Committee to Develop Guidelines for Management of Patients with Ventricular Arrhythmias and the Prevention of Sudden Cardiac Death) Developed in collaboration with the European Heart Rhythm Association and the Heart Rhythm Society. Eur Heart J 2006;27:2099-140.

3. Epstein AE, DiMarco JP, Ellenbogen KA, Estes NA, 3rd, Freedman RA, Gettes LS, Gillinov AM, Gregoratos G, Hammill SC, Hayes DL, Hlatky MA, Newby LK, Page RL, Schoenfeld MH, Silka MJ, Stevenson LW, Sweeney MO, American College of Cardiology F, American Heart Association Task Force on Practice G and Heart Rhythm S. 2012 ACCF/AHA/HRS focused update incorporated into the ACCF/AHA/HRS 2008 guidelines for device-based therapy of cardiac rhythm abnormalities: a report of the American College of Cardiology Foundation/American Heart Association Task Force on Practice Guidelines and the Heart Rhythm Society. Circulation. 2013;127:e283-352.

4. Chauvin M, Cazeau S, Frank R, Leenhardt A, Clémenty J, Barnay C, Djiane P, Salvador M, Boveda S, Defaye P. Recommendations from the French Cardiology Society concerning the competence, performance and the environment required for the implantation and surveillance of pacemakers. Arch Mal Coeur Vaiss. 2006;99:275-8.

5. Dodson JA, Lampert R, Wang Y, Hammill SC, Varosy P and Curtis JP. Temporal trends in quality of care among recipients of implantable cardioverter-defibrillators: insights from the National Cardiovascular Data Registry. Circulation. 2014;129:580-6.

6. Kirkfeldt RE, Johansen JB, Nohr EA, Jorgensen OD and Nielsen JC. Complications after cardiac implantable electronic device implantations: an analysis of a complete, nationwide cohort in Denmark. Eur Heart J. 2014;35:1186-94.

7. Al-Khatib SM, Hellkamp A, Bardy GH, Hammill S, Hall WJ, Mark DB, Anstrom KJ, Curtis J, Al-Khalidi H, Curtis LH, Heidenreich P, Peterson ED, Sanders G, Clapp-Channing N, Lee KL and Moss AJ. Survival of patients receiving a primary prevention implantable cardioverter-defibrillator in clinical practice vs clinical trials. JAMA. 2013;309:55-62.

8. Proclemer A, Muser D, Campana A, Zoni-Berisso M, Zecchin M, Locatelli A, Brieda M, Gramegna L, Santarone M, Chiodi L, Mazzone P, Rebellato L and Facchin D. Indication to cardioverter-defibrillator therapy and outcome in real world primary prevention. Data from the IRIDE [Italian registry of prophylactic implantation of defibrillators] study. Int J Cardiol. 2013; 168:1416-21.

9. Ascoeta MS, Marijon E, Defaye P, Klug D, Beganton F, Perier MC, Gras D, Algalarrondo V, Deharo JC, Leclercq C, Fauchier L, Babuty D, Bordachar P, Sadoul N, Boveda S, Piot O; DAI-PP Investigators. Impact of early complications on outcomes in 
patients with implantable cardioverter-defibrillator for primary prevention. Heart Rhythm. 2016;13:1045-51.

10. Escande W, Marijon E, Defaye P, Piot O, Leclercq C, Sadoul N, Deharo JC, Empana JP, Boveda S, Klug D. Electrical Storms in Patients With Implantable CardioverterDefibrillators for Primary Prevention. J Am Coll Cardiol. 2016;68:1248-50.

11. Perrin T, Mechulan A, Boveda S, Beganton F, Defaye P, Sadoul N, Piot O, Klug D, Gras D, Perier MC, Algalarrondo V, Bordachar P, Babuty D, Fauchier L, Leclercq C, Marijon E, Deharo JC; DAI-PP Investigators. Does defibrillation testing influence outcomes after CRT-D implantation? A cause-of-death analysis from the DAI-PP study.

Int J Cardiol. 2016 Oct 15;221:951-6.

12 Providência R, Boveda S, Defaye P, Segal O, Algalarrondo V, Sadoul N, Lambiase P, Piot O, Klug D, Perier MC, Bouzeman A, Barra S, Bories MC, Gras D, Fauchier L, Bordachar P, Babuty D, Deharo JC, Leclercq C, Marijon E; DAI-PP Investigators. Outcome of Primary Prevention Implantable Cardioverter Defibrillator Therapy According to New York Heart Association Functional Classification. Am J Cardiol. 2016;118:1225-32. 13. Providência R, Marijon E, Lambiase PD, Bouzeman A, Defaye P, Klug D, Amet D, Perier MC, Gras D, Algalarrondo V, Deharo JC, Leclercq C, Fauchier L, Babuty D, Bordachar P, Sadoul N, Piot O, Boveda S. Primary Prevention Implantable Cardioverter Defibrillator (ICD) Therapy in Women-Data From a Multicenter French Registry. $J$ Am Heart Assoc. 2016;5: pii: e002756.

14. Køber L, Thune JJ, Nielsen JC, Haarbo J, Videbæk L, Korup E, Jensen G, Hildebrandt P, Steffensen FH, Bruun NE, Eiskjær H, Brandes A, Thøgersen AM, Gustafsson F, Egstrup K, Videbæk R, Hassager C, Svendsen JH, Høfsten DE, Torp-Pedersen C, Pehrson S; DANISH Investigators. Defibrillator Implantation in Patients with Nonischemic Systolic Heart Failure. N Engl J Med. 2016;375(13):1221-30. 15. Boriani G, Berti E, Belotti LM, Biffi M, Carboni A, Bandini A, Casali E, Tomasi C, Toselli T, Baraldi P, Bottoni N, Barbato G, Sassone B. Cardiac resynchronization therapy: implant rates, temporal trends and relationships with heart failure epidemiology. $J$ Cardiovasc Med (Hagerstown). 2014;15:147-54.

16. Weeke P, Johansen JB, Jørgensen OD, Nielsen JC, Møller M, Videbæk R, Højgaard MV, Riahi S, Jacobsen PK. Mortality and appropriate and inappropriate therapy in patients with ischaemic heart disease and implanted cardioverter-defibrillators for primary prevention: data from the Danish ICD Register. Europace. 2013;15:1150-7.

17. Copie X, Piot O, Said MA, Lavergne T, Ollitrault J, Guize L and Le Heuzey JY. Temporal and geographical trends in indications for implantation of cardiac defibrillators in Europe 1993-1998. Medtronic ICD System Investigators. Pacing and clinical electrophysiology : PACE. 2000;23:979-84.

18. Bradshaw PJ, Stobie P, Briffa T and Hobbs MS. Use and long-term outcomes of implantable cardioverter-defibrillators, 1990 to 2009. Am Heart J. 2013;165:816-22.

19. Lin G, Meverden RA, Hodge DO, Uslan DZ, Hayes DL and Brady PA. Age and gender trends in implantable cardioverter defibrillator utilization: a population based study. $J$ Interv Cardiac Electrophysiol. 2008;22:65-70.

20. Santangeli P, Pelargonio G, Dello Russo A, Casella M, Bisceglia C, Bartoletti S, Santarelli P, Di Biase L and Natale A. Gender differences in clinical outcome and primary prevention defibrillator benefit in patients with severe left ventricular dysfunction: a systematic review and meta-analysis. Heart Rhythm. 2010;7:876-82.

21. Gauri AJ, Davis A, Hong T, Burke MC and Knight BP. Disparities in the use of primary prevention and defibrillator therapy among blacks and women. Am J Med. 2006;119:167 e17-21. 
22. Hernandez AF, Fonarow GC, Liang L, Al-Khatib SM, Curtis LH, LaBresh KA, Yancy CW, Albert NM and Peterson ED. Sex and racial differences in the use of implantable cardioverter-defibrillators among patients hospitalized with heart failure. JAMA. 2007;298:1525-32.

23. Mezu U, Ch I, Halder I, London B and Saba S. Women and minorities are less likely to receive an implantable cardioverter defibrillator for primary prevention of sudden cardiac death. Europace. 2012;14:341-4.

24. Al-Khatib SM, Hellkamp AS, Hernandez AF, Fonarow GC, Thomas KL, Al-Khalidi HR, Heidenreich PA, Hammill S, Yancy C, Peterson ED. Trends in use of implantable cardioverter-defibrillator therapy among patients hospitalized for heart failure: have the previously observed sex and racial disparities changed over time? Circulation.

2012;125:1094-101.

25. European Society of C, European Heart Rhythm A, Brignole M, Auricchio A, BaronEsquivias G, Bordachar P, Boriani G, Breithardt OA, Cleland J, Deharo JC, Delgado V, Elliott PM, Gorenek B, Israel CW, Leclercq C, Linde C, Mont L, Padeletti L, Sutton R and Vardas PE. 2013 ESC guidelines on cardiac pacing and cardiac resynchronization therapy: the task force on cardiac pacing and resynchronization therapy of the European Society of Cardiology (ESC). Developed in collaboration with the European Heart Rhythm Association (EHRA). Eur Heart J. 2013;34:2281-329.

26. Parkash R, Sapp JL, Basta M, Doucette S, Thompson K, Gardner M, Gray C, Brownell B, Kidwai $\mathrm{H}$ and Cox J. Use of primary prevention implantable cardioverterdefibrillators in a population-based cohort is associated with a significant survival benefit. Circ Arrhythm Electrophysiol. 2012;5:706-13.

27. Moss AJ, Zareba W, Hall WJ, Klein H, Wilber DJ, Cannom DS, Daubert JP, Higgins SL, Brown MW, Andrews ML and Multicenter Automatic Defibrillator Implantation Trial III. Prophylactic implantation of a defibrillator in patients with myocardial infarction and reduced ejection fraction. $N$ Engl J Med. 2002;346:877-83.

28. Bardy GH, Lee KL, Mark DB, Poole JE, Packer DL, Boineau R, Domanski M, Troutman C, Anderson J, Johnson G, McNulty SE, Clapp-Channing N, Davidson-Ray LD, Fraulo ES, Fishbein DP, Luceri RM, Ip JH and Sudden Cardiac Death in Heart Failure Trial I. Amiodarone or an implantable cardioverter-defibrillator for congestive heart failure. $N$ Engl J Med. 2005;352:225-37.

29. Voigt A, Shalaby A and Saba S. Continued rise in rates of cardiovascular implantable electronic device infections in the United States: temporal trends and causative insights. Pacing Clinical Electrophysiol. 2010;33:414-9.

30. Bhavnani SP, Giedrimiene D, Coleman CI, Guertin D, Azeem M and Kluger J. The healthcare utilization and cost of treating patients experiencing inappropriate implantable cardioverter defibrillator shocks: a propensity score study. Pacing Clinical Electrophysiol. 2014;37:1315-23.

31. Moss AJ, Schuger C, Beck CA, Brown MW, Cannom DS, Daubert JP, Estes NA, 3rd, Greenberg H, Hall WJ, Huang DT, Kautzner J, Klein H, McNitt S, Olshansky B, Shoda M, Wilber D, Zareba W and Investigators M-RT. Reduction in inappropriate therapy and mortality through ICD programming. N Engl J Med. 2012;367:2275-83.

32. Schwab JO, Gasparini M, Lunati M, Proclemer A, Kaup B, Santi E, Ligorio G, Klersy C, J DES, Okreglicki A, Arenal A, Wijffels M and Lemke B. Avoid delivering therapies for nonsustained fast ventricular tachyarrhythmia in patients with implantable cardioverter/defibrillator: the ADVANCE III Trial. J Cardiovasc Electrophysiol. 2009;20:663-6.

33. Sun S, Johnson J, Degroot P, Brown ML, Obel O. Effect of ICD Therapies on Mortality in the OMNI Trial. J Cardiovasc Electrophysiol. 2016;27:192-9. 
34. Moss AJ, Greenberg H, Case RB, Zareba W, Hall WJ, Brown MW, Daubert JP, McNitt S, Andrews ML, Elkin AD: Multicenter Automatic Defibrillator Implantation Trial-II (MADIT-II) Research Group: Longterm clinical course of patients after termination of ventricular tachyarrhythmia by an implanted defibrillator. Circulation. 2004;110:3760-5.

35. Poole JE, Johnson GW, Hellkamp AS, Anderson J, Callans DJ, Raitt MH, Reddy RK, Marchlinski FE, Yee R, Guarnieri T, Talajic M, Wilber DJ, Fishbein DP, Packer DL, Mark DB, Lee KL, Bardy GH: Prognostic importance of defibrillator shocks in patients with heart failure. N Engl J Med. 2008;359:1009-17.

36. Daubert JP, Zareba W, Cannom DS, McNitt S, Rosero SZ, Wang P, Schuger C, Steinberg JS, Higgins SL, Wilber DJ, Klein H, Andrews ML, Hall WJ, Moss AJ, MADIT II Investigators: Inappropriate implantable cardioverter-defibrillator shocks in MADIT II: Frequency, mechanisms, predictors, and survival impact. J Am Coll Cardiol. 2008;51:135765.

37. Sweeney MO, Sherfesee L, DeGroot PJ, Wathen MS, Wilkoff BL: Differences in effects of electrical therapy type for ventricular arrhythmias on mortality in implantable cardioverter-defibrillator patients. Heart Rhythm. 2010;7:353-60.

38. Deyell MW, Qi A, Chakrabarti S, Yeung-Lai-Wah JA, Tung S, Khoo C, Bennett MT, Qian H, Kerr CR: Prognostic impact of inappropriate defibrillator shocks in a population cohort. Heart. 2013;99:1250-5.

39. Saeed M, Hanna I, Robotis D, Styperek R, Polosajian LEO, Khan A, Alonso J, Nabutovsky Y, Neason C: Programming implantable cardioverter defibrillators in patients with primary prevention indication to prolong time to first shock: Results from the PROVIDE study. J Cardiovasc Electrophysiol. 2014;25:52-9.

40. Larsen JM, Hjortshøj SP, Nielsen JC, Johansen JB, Petersen HH, Haarbo J, Johansen MB, Thøgersen AM. Single-coil and dual-coil defibrillator leads and association with clinical outcomes in a complete Danish nationwide ICD cohort. Heart Rhythm. 2016;13:706-12.

41. Bougouin W, Marijon E, Puymirat E, Defaye P, Celermajer DS, Le Heuzey JY, Boveda S, Kacet S, Mabo P, Barnay C, Da Costa A, Deharo JC, Daubert JC, Ferrières J, Simon T, Danchin N; FAST-MI Registry Investigators. Incidence of sudden cardiac death after ventricular fibrillation complicating acute myocardial infarction: a 5-year cause-of-death analysis of the FAST-MI 2005 registry. Eur Heart J. 2014;35:116-22. 


\section{Figures and Tables}

Figure 1: Changes in the types of devices implanted between 2002 and 2012

VVI = single chamber ICD; DDD = dual chamber ICD; CRT-D = cardiac resynchronization therapy with back-up defibrillator.

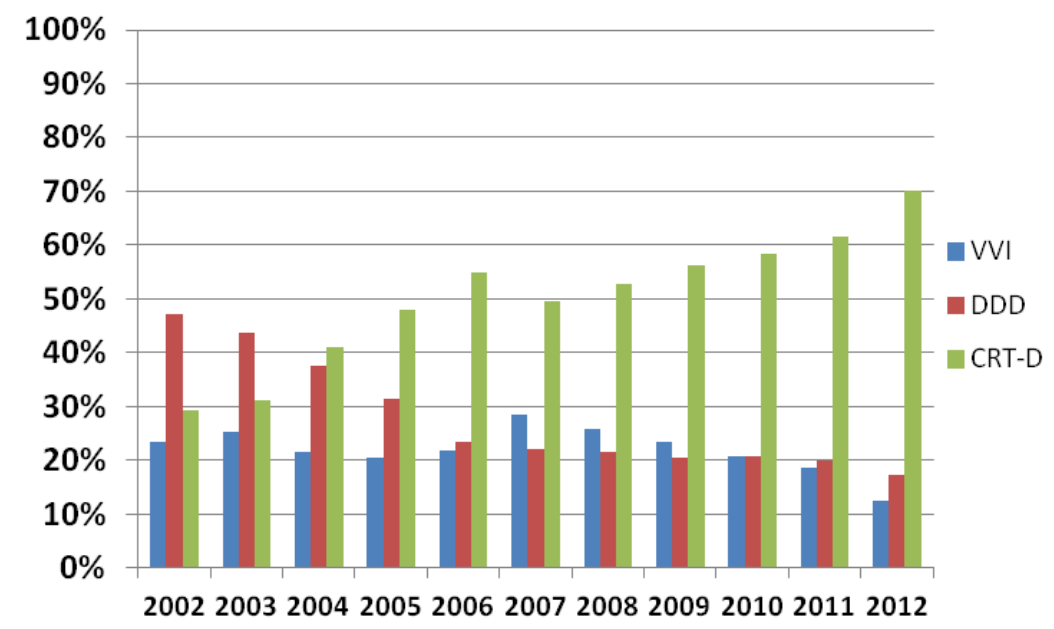


Figure 2: Baseline characteristics of the 5,539 implanted patients in the DAI-PP registry and according to the period of implantation 2002-2005, 2006-2009, 2010-2012.

In order to identify temporal trends during the period 2002 -2012, we arbitrarily decided to cut it in three periods (2002-2005; 2006-2009; 2010-2012) in order to provide comparison results between ancient and more recent periods of implantation and all these data were carefully analysed through these 3 time periods of implantation

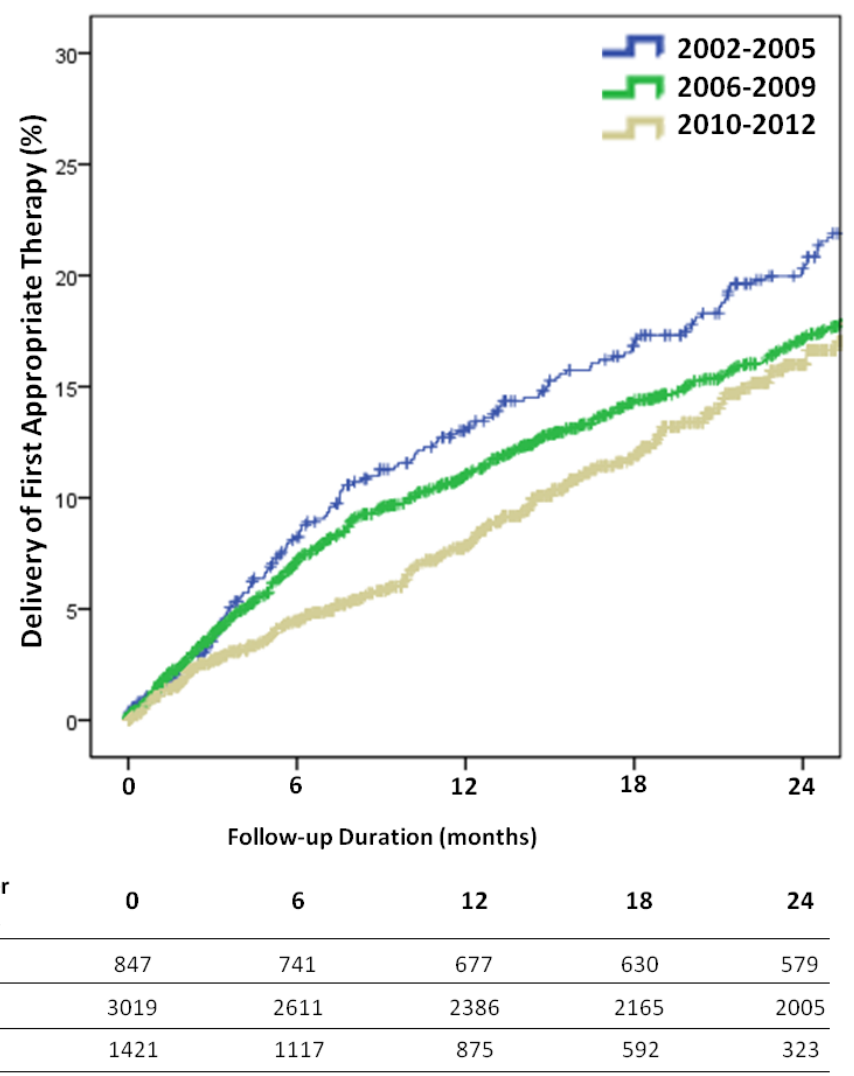


Table 1: Baseline characteristics and the 3 time periods temporal trends of the 5,539 participants in the DAI-PP registry

\begin{tabular}{|c|c|c|c|c|c|}
\hline Date of implantation & 2002-2012 & $2002-2005$ & $2006-2009$ & $2010-2012$ & $p$-value \\
\hline Number of patients & 5539 & 876 & 3155 & 1508 & \\
\hline Age, $y$ & $62.5 \pm 11.2$ & $61.5 \pm 11.6$ & $62.4 \pm 11.2$ & $63.2 \pm 10.9$ & 0.0016 \\
\hline Men & $4,702(84.9)$ & $776(88.6)$ & $2,657(84.2)$ & $1,269(84.2)$ & 0.0038 \\
\hline \multicolumn{6}{|l|}{ Dilated cardiomyopathy } \\
\hline Ischaemic & $3,304(60.2)$ & $598(69.0)$ & $1877(60.2)$ & $829(55.3)$ & \multirow{2}{*}{$<0.0001$} \\
\hline Non-ischaemic & $2,181(39.8)$ & $268(31.0)$ & $1242(39.8)$ & $671(44.7)$ & \\
\hline $\begin{array}{l}\text { Left ventricular ejection } \\
\text { Fraction, \% }\end{array}$ & $27 \pm 7$ & $26 \pm 8$ & $26 \pm 7$ & $27 \pm 6$ & 0.001 \\
\hline \multicolumn{6}{|l|}{ QRS duration, ms } \\
\hline$<120$ & $1,183(30.5)$ & $169(33.4)$ & $680(29.9)$ & $334(30.1)$ & \multirow{3}{*}{0.32} \\
\hline $120-150$ & $1,368(35.3)$ & $163(32.2)$ & $830(36.5)$ & $375(34.3)$ & \\
\hline$>150$ & $1,322(34.1)$ & $174(34.4)$ & $765(33.6)$ & $383(35.1)$ & \\
\hline $\begin{array}{l}\text { New York Heart Association } \\
\text { functional class }\end{array}$ & \multicolumn{4}{|c|}{ New York Heart Association } & \\
\hline I or II & $2,335(51.2)$ & $344(50.6)$ & $1320(50.8)$ & $671(52.2)$ & \multirow{2}{*}{0.68} \\
\hline III or IV & $2,227(48.8)$ & $335(49.3)$ & $1278(49.2)$ & $614(47.8)$ & \\
\hline Atrial fibrillation & $1,134(24.0)$ & $186(26.2)$ & $610(22.8)$ & $338(25.1)$ & 0.16 \\
\hline \multicolumn{6}{|l|}{ Concomitant illness(es) } \\
\hline 0 & $1,173(28.0)$ & $174(28.2)$ & $636(26.9)$ & $363(30.0)$ & \multirow{4}{*}{0.13} \\
\hline 1 & $2,339(55.9)$ & $345(56.0)$ & $1338(56.7)$ & $656(54.3)$ & \\
\hline 2 & $526(12.6)$ & $76(12.3)$ & $313(13.3)$ & $137(11.3)$ & \\
\hline$\geq 3$ & $147(3.5)$ & $21(3.5)$ & $73(3.1)$ & $53(4.4)$ & \\
\hline \multicolumn{6}{|l|}{ Device } \\
\hline $\begin{array}{l}\text { Single or dual chamber } \\
\text { cardioverter defibrillator } \\
\text { Cardiac resynchronization therapy } \\
\text { with back-up defibrillator }\end{array}$ & $2,538(46.2)$ & 485 (55.9) & $1458(46.8)$ & 595 (39.9) & $<0.0001$ \\
\hline \multicolumn{6}{|l|}{ Drug therapy } \\
\hline Beta-adrenergic blocker & $3,378(84.9)$ & $424(78.8)$ & $1,990(85.2)$ & $964(87.2)$ & $<0.0005$ \\
\hline $\begin{array}{l}\text { Angiotensin converting enzyme } \\
\text { inhibitor/angiotensin II receptor } \\
\text { blocker }\end{array}$ & $3,265(82.0)$ & $411(76.4)$ & $1,877(80.3)$ & $975(88.0)$ & 0.019 \\
\hline Antiplatelet agent & $2,278(57.2)$ & $374(50.9)$ & $1,333(57.0)$ & $671(60.7)$ & 0.016 \\
\hline Vitamin $\mathrm{K}$ antagonist & $1,404(35.3)$ & $2,000(37.2)$ & $807(34.5)$ & $397(35.9)$ & 0.32 \\
\hline Amiodarone & $902(22.7)$ & $122(22.7)$ & $545(23.3)$ & $235(21.3)$ & 0.81 \\
\hline Digoxin & $225(5.7)$ & $35(6.5)$ & $146(6.2)$ & $44(3.4)$ & 0.86 \\
\hline Furosemide & $2,709(68.1)$ & $310(57.6)$ & $1,611(68.9)$ & 788 (71.3) & 0.002 \\
\hline
\end{tabular}


Values are means \pm SD, numbers $(\%)$ of observations or median [IQR]. The percentages were calculated on the basis of the total number of known observations

Table 2: Risk analysis for all-cause mortality

\begin{tabular}{|c|c|c|c|c|c|c|}
\hline & \multicolumn{6}{|c|}{ Analysis } \\
\hline & \multicolumn{3}{|c|}{ Single variable } & \multicolumn{3}{|c|}{ Multiple variable } \\
\hline & HR & $95 \% \mathrm{CI}$ & $P$ & HR & $95 \% \mathrm{CI}$ & $P$ \\
\hline Female gender & 0.85 & $0.69-1.04$ & 0.120 & - & - & - \\
\hline History of atrial fibrillation & 1.73 & $1.48-2.03$ & $<0.001$ & 1.41 & $1.13-1.77$ & 0.003 \\
\hline Cardiac resynchronisation therapy & 1.57 & $1.36-1.81$ & $<0.001$ & - & - & - \\
\hline Age $>70$ years & 1.65 & $1.43-1.90$ & $<0.001$ & - & - & - \\
\hline New York Heart Association functional class $\geq$ III & 2.33 & $1.98-2.73$ & $<0.001$ & 2.25 & $1.81-2.79$ & $<0.001$ \\
\hline QRS >120 ms & 1.31 & $1.09-1.57$ & 0.003 & - & - & - \\
\hline Left ventricular ejection fraction $<30 \%$ & 1.50 & $1.29-1.74$ & $<0.001$ & 1.50 & $1.21-1.86$ & $<0.001$ \\
\hline Ischaemic heart disease & 1.22 & $1.05-1.42$ & 0.008 & 1.66 & $1.34-2.0$ & $<0.001$ \\
\hline Glomerular filtration rate $\leq 60 \mathrm{ml} / \mathrm{min}$ & 2.45 & $2.05-2.93$ & $<0.001$ & 2.31 & $1.88-2.84$ & $<0.001$ \\
\hline Appropriate shock or antitachycardia pacing & 0.94 & $0.80-1.10$ & 0.444 & - & - & - \\
\hline Inappropriate shock & 0.48 & $0.35-0.67$ & $<0.001$ & - & - & - \\
\hline
\end{tabular}

